\title{
'QUANTUM - COMPUTER - GENE', OR FOR THOSE WHO 'ALREADY KNOW EVERYTHING': POST-NON-CLASSICAL DISCLOSURES OF THE ARTISTIC PARADIGM OF JOY (J. S. FOER'S “EXTREMELY LOUD AND INCREDIBLY CLOSE”)
}

\author{
Roksoliana Kohan \\ PhD, Ivan Franko National University of Lviv, Ukraine \\ e-mail: roksolyana.kokhan@lnu.edu.ua, orcid.org/0000-0001-8639-9486
}

\begin{abstract}
Summary
The article foregrounds the relevance of scientific research, aimed at balancing the methodological fluctuations in the process of multi-study of the modern world through the lens of humanities. The society of today, characterized by deliberate transcending beyond the understandable and habitual use of technical advances, requires verbal comprehension other than classical formulations and hypotheses. In particular, universal phenomena (such as the phenomenon of joy) acquire a new (sometimes unpredictable) interpretation. The proposed study focuses on the artistic elaboration of the 'joy' category against the background of post-non-classical reality, followed by the subsequent refinement through analyzing Jonathan Safran Foer's novel "Extremely Loud and Incredibly Close".
\end{abstract}

Keywords: humanities, reception, artistic modeling, joy, poetics, methodology.

\section{DOI: https://doi.org/10.23856/3846}

The contemplation of the world, of oneself in the world and of the world in oneself is the transcendental circle that defines human existence. The whole interest of the humanities is in one way or another focused on the figure of a human being, his/her macro- and micro-place in the universe. Entering the depths of the human mentality and its comprehension against the contemporary background is due to literature. Being a 'mirror of the world perception', literature accepts, elaborates and reformats the reality. This feature of works of art as the 'art of the word' is especially relevant at the present stage of society's development, when leading technological advances are superimposed on the difficult 'coexistence' of generations $\mathrm{X}, \mathrm{Y}, \mathrm{Z}$ and Alpha (which provokes lively discussions and research interest of psychologists, culturologists, physiologists and specialists from other spheres). Absorbing reality and transforming it into a new 'now' is a challenge for every piece of art. For the sake of a more in-depth analysis of processing the modern times within the limits of artistic reality, we consider it appropriate to dwell on the particular dominant of the formatting of the world of a literary work. Given the peculiar polysemantics and paradigmatic nature, the category of joy seems interesting for the poetics study.

Comprehension, specification, and to some extent, generalizing the intention of joy in the 20th century, which traces its history to Democritus (and his interpretation of joy in the context of natural upbringing of personality), becomes possible when accepting the historical typology of philosophy as a science, of 'wisdom horizon' and 'word horizon' in the second half of the 20th century, acquiring a new development in the 21 st century.

For classical science, the definition and specification of the object of study, some empirical data, were particularly important. The discourse of accumulation and description of factual material naturally affected the fact that the object of the study was a system, either at rest or in 
equilibrium, and beyond external relations, interactions and interrelations. Post-non-classical science, on the other hand, seeks to recognize those moving elements of an open and unrestricted system that offer innumerable variations. The elaboration and dynamics of understanding joy as one of the key philosophical categories testifies to the tradition of a determined and purposeful scientific search.

The impetus for the transformation of a 'society of contemplation and consumption' into a 'society of action and attempt' has modified, apparently, personal thinking matrices. The novel by the American writer Jonathan Safran Foer "Extremely Loud and Incredibly Close" is interesting in the post-non-classical context. Written by the American journalist of Jewish descent, the novel about a child in New York after the events of September 11, 2001, becomes, to some extent, an ode to modernity: a man possesses almost every conceivable skill, the human hand is already capable of altering DNA, but in the world of discounts and suggestions a man has never been so lost, frustrated and impersonal before. The paradigmatic structure of joy (as a category) encompasses as many of its realizations (the expected ones and not as such), including those presented in J.S. Foer's novel.

The notion of 'I' (which, in the course of the plot's unfolding, will become a field of comprehension competition) is justifiably the compositional and meaningful center of the artistic model of the work. This concept has a significant textual panorama for representation and rapidly multiplies its meaning through the use not only of the verbal canon of literature but also by the active inclusion of visualization and symbolization means in the narrative space. The configural space of the narrative is built around one central figure, Oscar Shell, but none of the characters acquires a subordinated status (in terms of composition) / a status of subordination (in terms of reception and interpretation).

The American historian and philosopher of science, the critical rationalist Thomas Samuel Kuhn, substantiating the meaning of the concept of 'paradigm' (by proposing the term "disciplinary matrix" (Ryzhak, 2009: 196), emphasized the set of elements that form the sequence of modern science. Thus, combining the ideological landmarks, which are contradictory at first glance (death of the father and funeral without the body of the deceased - to make mother happy as one of the main "raisons d'etre" (Foer, 2006: 2), the paradigm of joy under canonical synergistic laws builds up to the matrix of global principles.

The events and discoveries that became significant for the emergence of non-classical science in the early twentieth century have dramatically influenced the humanities, its human-centered, partially diverse, vectors and approaches to comprehending oneself and the world. The conceptual series of initial scientific principles kaleidoscopically consists of such phenomena as the discovery of nuclear fission and the complex structure of the atom, the discovery of electron (John Thomson, 1897), determining the mass of electron's nucleus, and creation of a planetary model of the atom (Ernest Rutherford, 1911), development of a quantum model of the atom (Niels Bohr, 1913), emergence in the first quarter of the twentieth century of quantum mechanics, which studies microcosm (Max Planck, Max Born, Werner Heisenberg), V. Heisenberg's conclusion that the fundamental property of microcosm is the principle of uncertainty. At the same time, the twentieth century was marked by the study of the megaworld. The expediency and effectiveness of the technical and intellectual achievements of mankind are known to be determined by history. The main character of Foer's novel sees the 'existence' of the present as a very tragic gap, because "there are so many times when you need to make a quick escape, but people don't have their own wings, or not yet, anyway, so what about a birdseed shirt?" (Foer, 2006: 2). Such wings would have taken Thomas Shell, Oscar's father, away from tragic circumstances on September 9 and his son would not have had to think 
that it would be good to invent a teapot whose spout "reads in Dad's voice, so I could fall asleep, or maybe a set of kettles that sings the chorus of 'Yellow Submarine', which is a song by the Beatles" (Foer, 2006: 2). The foolish, unnecessary, sudden and incomprehensible death of the father devastated the child: "A lot of the time I'd get that feeling like I was in the middle of a huge black ocean, or in deep space, but not in the fascinating way" (Foer, 2006: 45). An opento-know childhood consciousness confronts the world of loss, pain and despair.

Describing a child who is too smart and interested, the author raised an important problem of mental development of the modern society, with a remarkable characteristic given by Mark Weiser, the former head of the Xerox PARC computer lab: "When people learn something well enough, they stop realizing it" (Kaiku, 2004: 43). People's lack of awareness of the value of their own knowledge and thinking creates the presence of others in the community- such as the Shells.

Karl Popper's belief that replacing the principle of cumulativeness of classical science comes with the principle of fallibilism (falsification) of non-classical science, when the absence of an empirical basis is a ground for denying the theory (Ryzhak, 2009), is, in our view, important for the formation of humanitarian research methodologies. Therefore, the value of scientific research is determined by its criticality, flexibility, ability to modify and change. Oscar Shell is an excessively emotional child ("I'm constantly emotional. - Are you emotional right now? 'I'm extremely emotional right now. - What emotions are you feeling? - All of them. Right now I'm feeling sadness, happiness, anger, love, guilt, joy, shame, and a little bit of humor, because part of my brain is remembering something hilarious that Toothpaste once did that I can't talk about" (Foer, 2006: 107) with a sensual and keen mind, combining the features of classical (where the ideal of episteme - absolutely authentic, demonstrative knowledge - was not an idol) and a modern thinker capable of 'permanent revolutions', where bold assumptions exist only to further refute them. Looking for yourself, or rather finding the answer to the question of whether there is a place for a person in life, is identified in the plot by the search for the castle, the key of which Oscar found among his father's belongings in the envelope with the inscription "Black": "Then I figured out that if a baby is born in New York every 50 seconds, and each person has 18 locks, and a new lock is created in New York every 2.777 seconds. So even if all I did was open locks. I'd still be falling behind by .333 locks every second. And that's if I didn't have to travel from one lock to the next, and if I didn't eat, and didn't sleep, which is an OK if, because I didn't actually sleep, anyway" (Foer, 2006: 21).

In order to study the paradigm of joy in the artistic text, it is important to emphasize that the methodology of post-non-classical science recognizes the pluralism of the development of self-organizing systems. At the same time, it is fundamentally important to "breach the principle of coherence", that is, it is probable that the development of self-organizing systems will result in situations where minor, local impacts lead to global consequences. Exploring the aspects of constructing the poetic paradigm of joy in literature, we focus on the recognition by the post-non-classical science of such objective, universal characteristics of reality as orderliness, structure, chaos, stochasticity, and chaos is seen not as the source of destruction, but only an important cognitive stage (Ryzhak, 2009: 382).

Oscar Shell 'strings' the 'dramatic units' and outlines a bizarre pyramid of meaning from individual puzzles of personal destinies, blurring the boundaries of the worlds (adult / child), where ontological planes inevitably transform each other: the novel about the child, absorbing the intensity of the novel about childhood, reaches the receptive level of philosophical and ideological knowledge. The dominant character provides narrative 'reproduction', which determines both the complexity and the variance of reception. 
On the path of finding and retrieving the meaning of the concept of 'joy' in the space of a literary work about children (childhood), it is especially valuable to adopt T. Kuhn's position, since the choice of a certain theory for the role of a paradigm will be based on a structured 'disciplinary matrix', each of which will acquire its own solution in the space of a literary work.

The system of characters acquires a special role from the standpoint of genre analysis of the novel, because it becomes possible for a multifaceted combination of different characteristics to create a holistic image of a work of art. By its own, systematic, principle, the model of the fictional world in Jonathan Safran Foer's novel 'grows' from the kaleidoscopic, 'multilayered' semantic levels, each dominated by a particular personal phenomenon (character, human destiny, key event in life, etc.). As you know, the character of the work centers the plot and action, structures the author's model and creative perception. In our opinion, a very limited and clearly defined large number of characters equally densify and saturate the plot of the work, depending on the intentions of the author.

A teenage boy, who knows that his father's coffin is empty, tries to understand how his dad died and to reveal the secret of the key found among his father's belongings. Receptive pre-assignment of the deferred known because of overcoming peculiar obstacles - each subsequent character constitutes an obstacle in the comprehension of the tragedy. The new quality of the semantic paradigm of joy is obtained precisely through the installation of narrative in the composition, through the dominance of symbolic stops (not identical in duration, as well as narrative and descriptive detalization) on the way of approaching the tragedy in the life of the teenager and his family.

The pronouncedly large number of characters takes on a special role in expressing a joyful context, which is primarily about understanding the problem of loneliness: a person feels alone when there are many people around (in fact, these many people are not one's surroundings). This problem becomes even more profound when it comes to a child who, as a teenager, 'accumulates' the tragic experience: pain of losing a dad, a grouch on the mother who is too quick (as Oscar seems) to find comfort in the company of her friend Ron, the inconvenience of touching the grandmother, blame for not picking up the phone when Dad called for the last time on "that day".

Thus, the classical and non-classical paradigms of science focused on the acquisition of true knowledge, whereas such aspects as the practical application of that knowledge, or what the social consequences would be, were relegated to secondary positions. Therefore, it seems quite natural to initiate and assert a new 'coil' in the upward spiral of scientific discourse. The post-non-classical paradigm of science appeals to anthropocentric determinism, to the creation - formation - meaning-making of the "human-measuring" systems.

Obviously, after the loss of the nearest and dearest, a person and the life of a single family became a generous field of reflections for the writer who has witnessed tragic events both for his homeland and for the entire world. A large number of characters (Oscar, his mom, father, grandmother, grandfather, grandmother's sister Anna, neighbor, new (very numerous) acquaintances, porter Stan, new mom's friend and others) and the montage of the novel's composition create an authentic picture of the 21 st century society.

The philosophical and methodological search for the conceptual origins of joy, the propaedeutic efforts to 'immerse' in the world of 'images and ideas' of literature about children, naturally comes within the context of the fundamental foundations of post-non-classical science, focused on the study of objects of a new type - self-regulating and self-organizing systems of different origin (natural, socio-cultural). Synergistic effects in the functioning of the system are manifested in the fact that even minor influences/interventions on/in the system are capable of 
causing a "chain reaction of consequences", and at the same time the level and effectiveness of this reaction can be completely inconsistent with the force of influence (I. Prigogine, H. Haken).

The main ideas of the theory of self-organization become the basis for a new paradigm of scientific knowledge, research and development of ideas (among other things) about the artistic and aesthetic space. The key principle of self-organization demonstrates the desire/ movement of the system to order and balance by overcoming/leveling/eliminating/minimizing entropy (disorder, chaos), therefore, the development of self-organizing systems is multivariate in nature.

The choice of tragedy for joyful depiction in the prism of childhood and in the eyes of a child is not accidental. Appealing to a child's character hides a double essence: on the one hand, it allows to penetrate into the depths of the child's insecure psyche and genuine emotions, but on the other hand, it imposes a special responsibility on the author and the reader in the process of encoding and decoding a serious mental problem that balances on the verge of childhood and adolescence.

In our opinion, the synergistic view of the world is in complete agreement with the idea declared by J.S. Foer on the pages of his novel: just as modern science requires anarchist epistemology, according to which all methodological prescriptions / rules have their limits, but the only invariable rule is "everything is permissible", which does not hinder the progress in scientific advance (P.K. Feyerabend), and for each individual consciousness in each case, all means and methods are possible in order to simply survive in the period, which is called "the era of opportunity".

Thus, the time of post-non-classical philosophy and science predetermined the development of post-non-classical aesthetics and literary studies (as well as humanities in general). On the one hand, there is a generalizing nature of the word, on the other - there is a meaningful need to refer/address the immediate (original, primary) life experience, "to the things themselves" (E. Husserl), and hence in the synthesis, struggle, contradiction and interaction, the intentions of the philosopher and the artist intersect / meet. A thought becomes reality, first it occurs as a premonition, then - as a foreboding, subsequently acquiring specification through the artistic world.

\section{References}

Dobronravova, I. (2014). Practical Philosophy of Postnonclassical Science about Scientific Truth and Human Freedom. Philosophy of Education, 15(2).

Foer, J. S. (2006). Extremely Loud And Incredibly Close. Houghton Mifflin Harcourt.

Kaiku, M. (2004). Vizii: yak nauka zminyt XXI storichchia. Lviv: Litopys. [in Ukrainian]

Kazyaryan, V. (2014). Complexity as a Characteristic of Postnonclassical Science. Liberal Arts in Russia, (3). doi:10.15643/libartrus-2014.6.1

Kun T. (2001). Struktura naukovykh revoliutsii. Kyiv: Port-Royal. [in Russian]

Lebedev, S. (2016). Postnonclassical philosophy of science: critical analysis. Voprosy fylosofyy y psykholohyy, 3(9). Bratislava: Academic Publishing House Researcher s.ro. 126-137. doi: 10.13187/vfp.2016.9.126

Lektorskii, V., Arshinov V., Kuznetsov V., Pruzhinin, B. (2016). Postnonclassical science and the sociocultural context. Herald of the Russian Academy of Sciences, 86(4), 343-350.

Ryzhak, L. (2009). Filosofiia yak refleksiia dukhu. Lviv. [in Ukrainian] 